\title{
IMPLEMENTASI NILAI PENDIDIKAN MULTIKULTURAL DI SEKOLAH DASAR (PENELITIAN DI MIS JAMALUDIN SAMPIH)
}

\author{
Neng Wardatushobariah \\ STIT Buntet Pesantren Cirebon \\ Email: wardatushobariah@gmail.com
}

\begin{abstract}
This study aims to describe, namely; 1). The role of the principal in implementing the value of multicultural education in schools, 2). The role of teachers in implementing the value of multicultural education in schools, 3). The importance of multicultural education for students at MIS JAMALUDDIN. The research method used is descriptive qualitative method with data sources obtained from school principals, teachers and students. The data analysis used is data collection, data reduction, data presentation, and conclusion drawing/verification. Data collection techniques are observation, interviews, and documentation to triangulation. The result of this research is the implementation of multicultural education values can be done through intracurricular activities in schools can be done by strengthening material about diversity, namely about various ethnic groups, cultures, religions and customs.
\end{abstract}

Keywords : Multicultural Education, Value of Multicultural Education, Madrasah Ibtidaiyah

\begin{abstract}
Abstrak
Penelitian ini bertujuan untuk mendeskripsikan yaitu; 1). Peran kepala sekolah dalam implementasi nilai pendidikan multikultural di sekolah, 2). Peran guru dalam mengimplementasikan nilai pendidikan multikultural di sekolah, 3). Pentingnya pendidikan multikultural bagi peserta didik di MIS JAMALUDDIN. Metode penelitian yang digunakan adalah metode kualitatif deskriptif dengan sumber data diperoleh dari kepala sekolah, guru dan siswa. Analisis data yang digunakan yaitu pengumpulan data, reduksi data, penyajian data, dan penarikan kesimpulan/ferivikasi. Teknik pengumpulan data yaitu observasi, wawancara, dan dokumentasi hingga triangulasi. Hasil dari penelitian ini adalah implementasi nilai pendidikan multikultural dapat dilakukan melalui kegiatan intrakurikuler disekolah dapat dilakukan dengan penguatan materi tentang keberagaman yaitu tentang beragam suku, budaya, agama dan adat istiadat.
\end{abstract}

Kata Kunci : Pendidikan Multikultural, Nilai Pendidikan Multikultural, Madrasah Ibtidaiyah

\section{Pendahuluan}

Keragaman merupakan identitas bangsa Indonesia. Multikultural di Indonesia bersifat budaya antar etnis yang kecil, yaitu budaya antar suku bangsa. Keragaman budaya datang dari dalam bangsa Indonesia sendiri. Oleh karenanya, pendidikan multikultural menekankan pentingnya akomodasi hak setiap kebudayaan dan masyarakat sub-nasional untuk memelihara dan mempertahankan identitas kebudayaan dan masyarakat nasional. Sehingga dalam penerapannya 
sangat diperlukan adanya sikap toleransi, cinta damai, dan jujur.

$$
\text { Khoirul Mahfud }
$$

menjelaskan bahwa Keragaman masyarakat Indonesia menuntut rasa saling toleransi, menghormati dan menghargai antar perbedaan tersebut. Keragaman yang ada sering mengakibatkan diskriminasi yang berujung pada konflik dan kekerasan. Negara kita seringkali dilanda konflik dan kekerasan antar masyarakat yang dapat menyebabkan perpecahan, baik itu konflik etnis maupun konflik antar pemeluk agama. Upaya mengatasi permasalahan yang disebabkan oleh keragaman bangsa tersebut salah satunya adalah melalui jalur pendidikan.

Pendidikan adalah usaha sadar yang dilaksanakan melalui proses pembelajaran untuk mengembangkan potensi peserta didik yang berguna bagi dirinya, masyarakat dan negara (Undang-Undang RI No. 20 Tahun 2003 Bab 1 Pasal 1 ayat

Seiring banyaknya permasalahan yang muncul disebabkan oleh keragaman tersebut, maka lahir pemikiran untuk mengembangkan pendidikan multikultural di Indonesia. Khoirul Mahfud (2016:216) menjelaskan bahwa penyelenggaraan pendidikan multikultural di dunia pendidikan diyakini dapat menjadi solusi nyata bagi konflik dan disharmonisasi yang terjadi di masyarakat, khususnya yang kerap terjadi di masyarakat Indonesia yang secara realitas adalah masyarakat yang plural. Dengan kata lain, pendidikan multikultural dapat menjadi sarana alternatif pemecah konflik sosialbudaya. Selain sebagai sarana alternatif pemecahan konflik, Khoirul Mahfud (2016:218) juga menjelaskan bahwa pendidikan multikultural juga signifikan dalam membina siswa agar tidak tercerabut dari akar budaya yang ia miliki sebelumnya, tatkala ia berhadapan dengan realitas sosial budaya di era globalisasi.

Pendididikan multikultural dapat diaplikasikan ke dalam semua jenis mata pelajaran yang mengakomodir perbedaanperbedaan kultural yang ada pada peserta didik. Seperti perbedaan etnis, agama, bahasa, gender, kelas sosial, kemampuan dan umur. Penerapan pendidikan multikultural di sekolah terkadang memang sangat belum diperhatikan, terutama pada peserta didik. Jika dipahami sebenarnya penerapan sikap saling toleransi dan menghormati satu sama lain sangatlah penting baik di lingkungan peserta didik maupun di lingkungan dewan guru. Kekuatan yang paling menonjol dalam pendidikan multikultural pada peserta didik adalah bagaimana kemampuan mereka menerima perbedaan sebagai sesuatu yang wajar. Penerapan pendidikan multikultural sangat penting untuk meminimalisasi dan mencegah terjadinya konflik di beberapa daerah.

Melalui pendidikan multikultural, sikap dan mindset (pemikiran) siswa akan lebih terbuka untuk memahami dan menghargai keberagaman. Banks (dalam Amrazi Zakso, 2011:134) menyatakan bahwa ada 5 dimensi pokok dalam pendidikan multikultur, yakni : (a). content integration, (b). knowledge construction process, (c). prejudice reduction, (d). equity pedagogi, dan (e). empowering school culture (Banks, 1989;1991;1993).

Kategorisasi dimensi pendidikan multikultur ini tidak mutual exclusive, boleh jadi ada dimensi yang tumpang tindih. Namun, pengkategorisasian seperti ini sangat dibutuhkan untuk mempermudah konseptualisasi pendidikan multikultur. Untuk mengembangkan pendidikan 
multikultur, proses pembelajaran di sekolah juga harus bermuatan multikultural (Amrazi Zakso,2011:135).

Desmita (2016) menjelaskan bahwa anak usia sekolah dasar 7 sampai 11 tahun berada pada tahap mythic- literal faith. Tahap perkembangan kognitifnya, berada pada perkembangan operasional konkret yakni memikirkan segala sesuatunya secara konkret; anak secara sistematis mulai mengambil makna tradisi masyarakatnya. Guru harus memahami karakteristik dan keberagaman peserta didik di sekolah, agar mampu mengelola kesetaraan guna meningkatkan kualitas pendidikan.

Hanum (2009) menyatakan tujuan utama pendidikan multikultural mengubah pendekatan pembelajatan kearah memberi peluang yang sama pada setiap peserta didik, yakni: 1). Tidak ada yang dikorbankan demi persatuan; 2). Siswa ditanamkan pemikiran lateral, keanekaragaman; 3). Keunikan itu juga dihargai. Hal ini berarti harus ada perubahan sikap, perilaku, dan nilai-nilai khususnya civitas akademika sekolah. Penekanan pemdidikan multikultural lebih difokuskan pada pendidikannya. Siswa seharusnya dilatih dan dibiasakan untuk memahami semua jenis pengetahuan, aktif mendiskusikan konstruksi pengetahuan dan interpretasi.

Disadari atau tidak siswa sekolah dasar saat ini telah memasuki zona budaya maya bahkan menjadi aktor sekaligus korban dalam wilayah geografi mental tersebut. Tidak lagi menjadi hal baru dan mengherankan bahwa anak-anak sekolah dasar di kota bima khususnya di desa sangiang mempunyai akun pribadi seperti facebook, instagram, whatsaap, dan telegram sehingga kapan saja dapat mengupdate statusnya, merekayasa gambar, berita, dan memposting ke wilayah publik. Siswa sekolah dasar sudah mampu mendeskripsikan dirinya dengan bebas dengan siapa pun, merasa ok, hebat, terkenal dan berlomba mengumpulkan teman sebanyak-banyaknya di media sosial. Wilayah sosial siswa tidak lagi dibatasi tembok rumah dan halaman sekolah tetapi diukur oleh kemampuan dan waktu mereka berkutat menjagkau siapapun dan apapun dengan teknologi informasi (Dike:2017).

Adapun implementasi pendidikan multikultural di sekolah dapat disesuaikan dengan jenjang pendidikan dan umur siswa. Sehingga implementasi pendidikan multikultural dapat dilakukan dengan cara sebagai berikut. Yaya Suryana dan Rusdiana, Pendidikan Multikultural Suatu Upaya Penguatan Jati Diri Bangsa, (Bandung: Pustaka Setia, 2015,213-215).

1. Implementasi Pendekatan Kontribusi di Kelas Pada siswa TK dan SD kelas bawah (kelas I, II, III) implementasi pendidikan multikultural dapat 
dilakukan dengan pendekatan kontribusi, antara lain dengan cara:

a. Memperkenalkan beragam bentuk rumah dan baju adat dari etnis yang berbeda.

b. Mengajak siswa untuk mencicipi makanan yang berbeda dari berbagai daerah secara bergantian.

c. Mendengarkan lagu-lagu daerah lain.

d. Menunjukkan cara berpakaian yang berbeda, baik dari suku bangsa maupun dari negara lain.

e. Memperkenalkan tokoh-tokoh pejuang dari berbagai daerah dalam dan luar negeri.

f. Menunjukkan tempat dan cara beribadah yang berbeda.

g. Meminta siswa yang berbeda etnis untuk menceritakan tentang uparaca perkawinan di keluarga luasnya.

h. Memperkenalkan beberapa kosa kata penting yang berasal dari suku bangsa atau negara (ras) lain. Misalnya: matur nuwun (Jawa), muliate (Batak), thank you (Inggris), kamsia (Cina), dan sebagainya.

i. Memperkenalkan panggilan untuk laki-laki dan perempuan. Misalnya, upik (Minangkabau), ujang (Sunda), koko (Cina), dan sebagainya. Substansi pendidikan multikultural pada tahab ini adalah menanamkan pada siswa bahwa manusia yang hidup disekitarnya, di tempat lain, dan di dunia ini sangat beragam. Sebenarnya semua nilainya sama. Sama-sama rumah, makanan, lagu, pakaian, tokoh ibadah, perkawinan, maksud kata dan sebagainya. Dengan demikian, siswa mulai mengerti bahwa ada cara yang berbeda, tetapi maksud dan nilainya sama sehingga dapat belajar untuk menerima perbedaan dengan proses rasa yang menyenangkan. Akhirnya, siswa merasa berbeda bukanlah masalah, melainkan anugerah.

2. Implementasi Pendidikan Aditif di Kelas Siswa SD kelas (IV, V, VI) dan SMP sudah mulai mampu memahami makna pendekatan aditif tepat untuk diberikan, seperti:

a. Melengkapi perpustakaan dengan buku-buku cerita rakyat dari berbagai daerah dan negara lain.

b. Membuat modul pendidikan multikultural untuk suplemen materi pelajaran yang lain, seperti Modul Pendidikan Multikultural untuk suplemen pendidikan IPS kelas IV (Farida Hanum dan Setya Raharja, 2006).

c. Memutarkan CD tentang kehidupan di pedesaaan, di perkotaan, dari daerah dan negara yang berbeda.

d. Meminta siswa memiliki teman korespondensi /e-mail/ facebook atau sahabat dengan siswa yang berbeda daerah, negara, atau latar belakang lainnya.

e. Menceritakan pengetahuan dan pengalaman guru tentang materi di daerah atau negara lain. Misalnya, guru IPA menjelaskan macammacam tanaman dan hewan, guru Bahasa Indonesia menceritakan penyair, guru IPS menjelaskan sejarah bangsa.

f. Mengintegrasikan nilai-nilai multikultural dan menerapkannya di kelas. Hal tersebut dilakukan untuk menanamkan pengetahuan yang luas bagi siswa. Rasa ketertarikan 
akan keragaman yang diperoleh di dalam kelas akan memotivasi siswa untuk tahu lebih banyak dengan membaca, melihat di internet, berkunjung, bertanya kepada orang yang lebih tahu, dan sebagainya.

(2018)

Kemudian penelitian Najmina multikulturalisme harus diterapkan dalam proses pembelajaran melalui proses pembiasaan, pembelajaran multikultural dilakukan dengan pembentukan pola pikir, sikap, tindakan, dan pembiasaan sehingga muncul kesadaran nasional keIndonesiaan. Karakter keindonesiaan tersebut meliputi: kesadaran kebanggaan sebagai bangsa, kemandirian dan keberanian sebagai bangsa, kesadaran kehormatan sebagai bangsa, kesadaran melawan penjajahan, kesadaran berkorban demi bangsa, keasadaran nasionalisme bangsa lain, dan kesadaran kedaerahan menuju kebangsaan. Terwujudnya karakter keindonesiaan tersebut menjadi landasan kuat sebagai ciri khas manusia Indonesia yang kuat.

Tujuan penelitian pada artikel ini adalah untuk mendeskripsikan dan menganalsisis implementasi nilai-nilai pendidikan multikultural di MIS Jamaluddin, Kab. Cirebon. Secara rinci yaitu: 1). Mendeskripsikan peran kepala sekolah dalam implementasi nilai pendidikan multikultual di sekolah, 2). Mendeskripsikan peran guru dalam mengimplementasikan nilai pendidikan multikultural di sekolah, dan 3). Mendeskripsikan pentingnya pendidikan multikultural bagi peserta didik sekolah dasar.

\section{Metode}

Penelitian ini menggunakan pendekatan kualitatif dengan metode deskriptif. Penelitian kualitatif dengan metode deskriptif adalah metode yang menjelaskan atau mendeskripsikan suatu fakta, data, dan objek penelitian secara sistematis dan sesuai dengan situasi alamiah. Terkait hal yang diteliti, hasil penelitian lebih menekankan pada makna dari pada hasil, dan hasil penelitian tidak mengikat serta dapat berubah sesuai dengan kondisi yang dihadapi di lapangan penelitian dan diinterpretasikan dan dituliskan dalam bentuk kata-kata atau deskriptif berdasarkan fakta di lapangan (Anggito \& Setiawan, 2018).

Penelitian ini dilaksanakan di MIS Jamaluddin Desa Sampih Kec. Susukanlebak Kab. Cirebon dengan sumber data penelitian yaitu informan (Kepala Sekolah, Guru, dan Peserta didik). Peneliti berperan sebagai human instrument (peneliti melakukan penelitiannya sendiri). Teknik pengumpulan data menggunakan wawancara, observasi, dan dokumentasi (Moleong, 2017). Analisis data bersifat kualitatif, dengan menggunakan model Milles \& Huberman yaitu Reduksi data, Penyajian data dan kesimpulan atau Verifikasi (Miles \& Huberman, 2013). Dan adapun teknik pemeriksaan keabsahan data yang digunakan adalah: triangulasi data, meningkatkan ketekunan, dan menggunakan bahan referensi (Sugiyono, 2018).

\section{Hasil dan Pembahasan}

\subsection{Hasil Penelitian}

Pada bagian ini akan jelaskan hasil penelitian berdasarkan hasil wawancara dan obeservasi yang dilakukan oleh peneliti tentang 1) Peran kepala sekolah dalam mengimplementasikan nilai Pendidikan multikultural, 2) Peran guru dalam 
mengimplementasikan nilai Pendidikan multikultural, dan 3) Pentingnya pendidikan multikultural bagi peserta didik, sebagai berikut:

Tabel .1. Hasil Observasi

\begin{tabular}{|c|c|c|}
\hline $\begin{array}{c}\text { Aspek } \\
\text { yang } \\
\text { diamati }\end{array}$ & $\begin{array}{l}\text { Deskripsi aspek } \\
\text { yang diamati }\end{array}$ & $\begin{array}{l}\text { Kesimpul } \\
\text { an }\end{array}$ \\
\hline $\begin{array}{l}\text { Peran } \\
\text { kepala } \\
\text { sekolah } \\
\text { dalam } \\
\text { implemen } \\
\text { tasi nilai } \\
\text { pendidika } \\
\text { n } \\
\text { multikukt } \\
\text { ural }\end{array}$ & 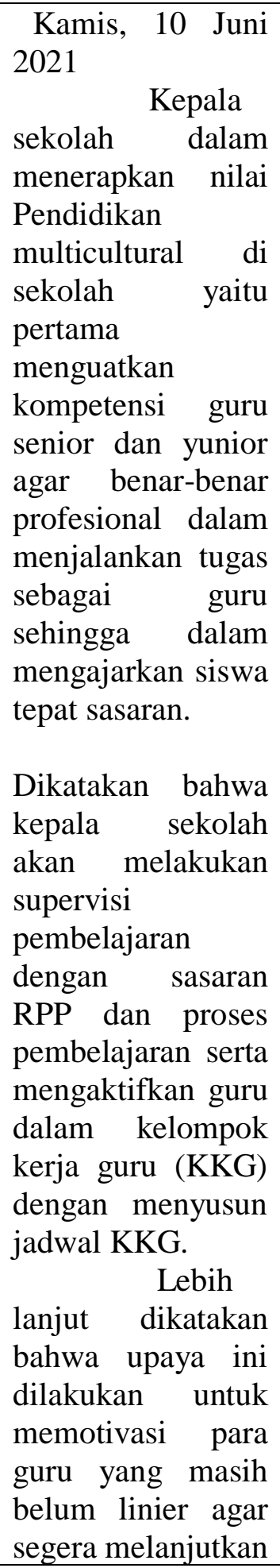 & $\begin{array}{l}\text { Kepala } \\
\text { sekolah } \\
\text { dalam } \\
\text { mengimple } \\
\text { mentasi nilai } \\
\text { Pendidikan } \\
\text { multicultura } \\
\text { 1 pada } \\
\text { peserta didik } \\
\text { di SD yaitu: } \\
\text { 1) Menguatkan } \\
\text { Mempetensi } \\
\text { guru senior } \\
\text { dan yunior, } \\
\text { 2) g) and } \\
\text { membina } \\
\text { guru agar } \\
\text { dapat } \\
\text { melakukan } \\
\text { supervise } \\
\text { pembelajara } \\
\text { n dengan } \\
\text { sasaran } \\
\text { RPP, proses } \\
\text { pembelajara } \\
\text { n mengaktifka } \\
\text { n KKG } \\
\text { 3) memotivasi } \\
\text { para guru } \\
\text { agar bisa } \\
\text { melanjutkan } \\
\text { studi liner } \\
\text { baik D3, S1, } \\
\text { dan S2. }\end{array}$ \\
\hline
\end{tabular}

\begin{tabular}{|c|c|c|}
\hline & $\begin{array}{l}\text { studinya misalnya } \\
\text { dari S1 PGSD ke } \\
\text { S2 PGSD atau dari } \\
\text { D3 PGSD ke S1 } \\
\text { PGSD hal ini saya } \\
\text { lakukan untuk } \\
\text { meningkatkan } \\
\text { kapasitas guru di } \\
\text { sekolah yang saya } \\
\text { pimpin yang } \\
\text { nantinya akan } \\
\text { dapat mengimpelmentasi } \\
\text { men nilai-nilai } \\
\text { kan pendidikan } \\
\text { multikultural pada } \\
\text { peserta didik. }\end{array}$ & \\
\hline $\begin{array}{l}\text { Peran } \\
\text { guru } \\
\text { dalam } \\
\text { mengimp } \\
\text { lementasi } \\
\text { kan nilai } \\
\text { pendidika } \\
\text { n } \\
\text { multikult } \\
\text { ural }\end{array}$ & $\begin{array}{l}\text { Kamis, } 10 \text { Juni } \\
2021 \\
\text { Pada intinya } \\
\text { peran guru dalam } \\
\text { implementasi nilai } \\
\text { pendidikan } \\
\text { multikultural di } \\
\text { sekolah yaitu: } \\
\text { dengan melalui } \\
\text { kegiatan } \\
\text { intrakurikuler dan } \\
\text { ekstrakulikuler. } \\
\text { Dalam kegiatan } \\
\text { intrakurikuler } \\
\text { misalnya guru } \\
\text { selalu memberikan } \\
\text { pengajaran dan } \\
\text { pemahaman } \\
\text { kepada peserta } \\
\text { didik petingnya } \\
\text { menjaga } \\
\text { keberagaman dan } \\
\text { guru melakukan itu } \\
\text { melalui penguatan } \\
\text { materi keberagaman di } \\
\text { kebelas. } \\
\text { Sabtu, 12 Juni } \\
\text { 2021 Guru ketika } \\
\text { diskusi dengan } \\
\text { siswa di kelas tetap }\end{array}$ & $\begin{array}{l}\text { Guru dalal } \\
\text { mengimpleme } \\
\text { ntasi nil } \\
\text { pendidikan } \\
\text { multikultural } \\
\text { di sekola } \\
\text { yaitu: } \\
\text { melalui } \\
\text { kegiatan } \\
\text { intrakurikuler } \\
\text { dan } \\
\text { ekstrakulikule } \\
\text { intrakurikuler } \\
\text { misalnya gur } \\
\text { selalu } \\
\text { memberikan } \\
\text { pemahaman } \\
\text { kepada peser } \\
\text { didik didi } \\
\text { kelas. }\end{array}$ \\
\hline
\end{tabular}

Neng Wardatushobariah 


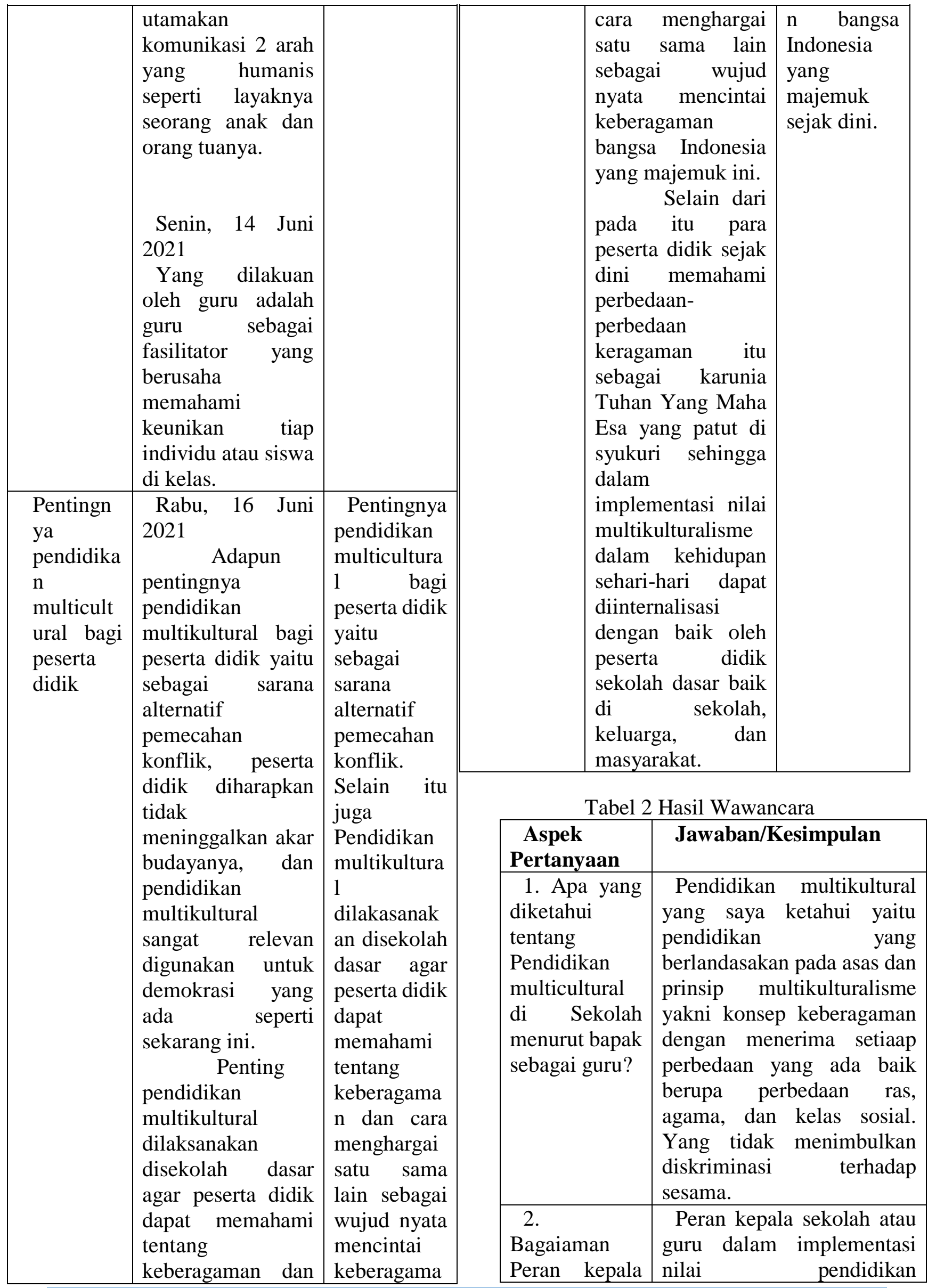




\begin{tabular}{|c|c|}
\hline $\begin{array}{l}\text { sekolah/guru } \\
\text { dalam } \\
\text { menerapkan } \\
\text { nilai } \\
\text { pendidikan } \\
\text { multicultural? }\end{array}$ & $\begin{array}{l}\text { multicultural di sekolah } \\
\text { dasar yaitu yaitu: melalui } \\
\text { kegiatan intrakurikuler dan } \\
\text { ekstrakulikuler. } \\
\text { kegiatan Pada } \\
\text { misalnya guru selalu } \\
\text { memberikan pemahaman } \\
\text { kepada peserta didik didik } \\
\text { kelas. Sementara Kegiatan } \\
\text { ektrakurikuler adalah kemah } \\
\text { budya, karnaval pakaian } \\
\text { adat istiadat tiap-tiap daerah } \\
\text { yang ada di indonesia serta } \\
\text { pendalaman nilai tentang } \\
\text { bhineka tunggal ika dan } \\
\text { pancasila }\end{array}$ \\
\hline $\begin{array}{l}\text { 3. Seberapa } \\
\text { Penting } \\
\text { pendidikan } \\
\text { multicultural } \\
\text { bagi peserta } \\
\text { didik di } \\
\text { sekolah? }\end{array}$ & $\begin{array}{l}\text { Pentinya pendidikan } \\
\text { multicultural bagi peserta } \\
\text { didik adalah sebagai suatu } \\
\text { dasar yang menjadi modal } \\
\text { peserta didik dalam } \\
\text { kehidupan lebih lanjut, } \\
\text { karena Negara Indonesia } \\
\text { memiliki berbagai macam } \\
\text { suku, budaya dan agama } \\
\text { maka penanaman nilai } \\
\text { multural dalam Pendidikan } \\
\text { dasar adalah suatu wujud } \\
\text { nyata dari persiapan } \\
\text { kehidupan yang akan } \\
\text { datang. Nilai-nilai yang akan } \\
\text { ditanamkan adalah } \\
\text { mencintai keberagamaan, } \\
\text { Nasionalisme, Karakter, } \\
\text { kejujuran dan kepribadian } \\
\text { yang tanggung jawab. }\end{array}$ \\
\hline $\begin{array}{l}\text { 4. Apa saja } \\
\text { kegiatan yang } \\
\text { dilakukan oleh } \\
\text { peserta didik } \\
\text { sebagai wujud } \\
\text { nyata } \\
\text { implementasi } \\
\text { dari nilai } \\
\text { multicultural? }\end{array}$ & $\begin{array}{l}\text { Adapun kegiatan yang } \\
\text { dilakukan oleh peserta didik } \\
\text { dan sekolah dalam } \\
\text { mengimplementasi nilai } \\
\text { Pendidikan multicultural } \\
\text { adalah kegiatan pameran } \\
\text { keagamaan yang } \\
\text { menghadirkan pakaian dan } \\
\text { bentuk agama yang ada di } \\
\text { Indonesia, karnaval dengan } \\
\text { memakai baju adat } \\
\begin{array}{l}\text { Indonesia dari berbagai } \\
\text { daerah. }\end{array}\end{array}$ \\
\hline
\end{tabular}

\begin{tabular}{|l|l|}
\hline \multicolumn{1}{|c|}{ 5. Adakah } & \multicolumn{1}{|c|}{ Adapu program khusus } \\
program & yang dilakukan oleh sekolah \\
khusus yang & adalah dengan menanamkan \\
dilakukan oleh & nilai multikulturalisme pada \\
sekolah dalam & papan Karakter yang di \\
menumbuhkan & temple di dinding, dan di \\
nilai & muat juga dalam \\
mulyikultural & pembelajaran di kelas dan \\
pada peserta & diluar kelas \\
didik? & \\
\hline
\end{tabular}

\subsection{Pembahasan Penelitian}

Pelaksanaan pendidikan multikultural dalam kehidupan di MIS Jamaluddin. Dilakukan melalui kegiatan intrakurikuler. Kegiatan tersebut dilakukan dengan sangat beragam, dan disesuaikan dengan minat dan bakat peserta didik. Hal ini dilakukan agar peserta didik dapat mempraktikan secara langsung sesuai dengan dunia nyata. Kegiatan intrakurikuler disekolah dapat dilakukan dengan penguatan materi tentang keberagaman yaitu tentang beragam suku, budaya, agama dan adat istiadat. Dalam proses implementasi pendidikan multukultural tersebut juga tidak terlepas dari peran penting dari kepala sekolah, guru, dan siswa. Karena itu proses implementasi nilai-nilai pendidikan multikultural dapat dijelaskan secara rinci berdasarkan peran kepala sekolah, guru, dan peserta didik. Hal tersebut dapat dijelaskan sebagai berikut:

\subsubsection{Peran Kepala Sekolah dalam Mengimplementasikan Nilai Pendidikan Multikultural}

Berdasarkan hasil observasi dan wawancara dengan kepala sekolah melalui via telepon seluler pada hari kamis 10 Juni 2021 yang menyatakan "Saya dalam mengimplementasikan nilai pendidikan multikultural si sekolah 
yaitu pertama saya kuatkan kompetensi guru senior dan yunior agar benar-benar profesional dalam menjalankan tugas sebagai guru sehingga dalam mengajarkan siswa tepat sasaran. Lebih lanjt dia katakan, dan saya melakukan supervisi pembelajaran dengan sasaran RPP dan proses pembelajaran serta mengaktifkan guru dalam kelompok kerja guru (KKG) dengan menyusun jadwal $\mathrm{KKG}$, saya pun memotivasi para guru yang masih belum linier agar segera melanjutkan studinya misalnya dari S1 PGSD ke S2 PGSD atau dari D3 PGSD ke S1 PGSD hal ini saya lakukan untuk meningkatkan kapasitas guru di sekolah yang saya pimpin yang nantnya akan dapat mengimpelmentasikan nilai-nilai pendidikan multikultural pada peserta didik, tutupnya" (W.KS.10.06.2021).

Peran kepala sekolah dalam mengimplementasikan pendidikan multikultural di sekolah yaitu: (1) menugaskan guru senior membina guru yunior untuk meningkatkan kompetensi guru terutama kompetensi profesional; membina guru dengan melaksanakan supervisi pembelajaran dengan sasaran Rancangan Pelaksanaan Pembelajaran (RPP) dan proses pembelajaran di kelas; (3) mengaktifkan guru dalam kelompok kerja guru (KKG) dengan cara menyusun jadwal kegiatan KKG dan memantaunya setiap minggu sekali dan paling sedikit sebulan sekali dengan membahas tentang permasalahan pembelajaran; (4) kepala sekolah menugaskan guru mengikuti kegiatan seminar atau penataran berdasarkan materi dan minat guru dan memotivasi guru supaya melakukan studi lanjut untuk meningkatkan kualifikasi guru dari D2 PGSD ke S1 PGSD atau dari S1 PGSD ke S2 PGSD; (5) mengusulkan guru untuk mengikuti sertifikasi guru dan membina guru yang sudah lulus sertifikasi guru; (6) membimbing guru dalam melaksanakan penelitian tindakan kelas (PTK) mulai dari cara menyusun proposal penelitian, cara melaksanakan penelitian dan cara menyusun laporan hasil penelitian tindakan kelas.

3.2.2. Peran Guru dalam

Mengimplemantasikan Nilai Pendidikan Multikultural Guru merupakan ujung tombak dalam mengimplementasikan nilai-nilai pendidikan multikultural di sekolah. Dalam usaha menentukan keberhasilan pemahaman lintas budaya peserta didik, cara mengajar, kepribadian guru, materi pembelajaran dapat mempengaruhi keberhasilan proses pembelajaran dalam mendukung pengembangan situasi dan kondisi yang kondusif di sekolah berdasarkan pada kehidupan mutltikultural bagi warga sekolah khususnya dan masyarakat sekitar pada umumnya (Gaharu, 2014). 
Kegiatan pembelajaran pendidikan multikultural menurut Zubaidi (2004: 77) adalah guru dituntut mau dan mampu menerapkan strategi pembelajaran kooperatif harus menerapkan di antaranya: adanya saling ketergantungan, adanya interaksi tatap muka yang membangun, pertanggung jawaban secara individu, ketrampilan sosial dan efektivitas proses pembelajaran dalam kelompok. Sekolah yang mengelola pendidikan berdasarkan multikultural senantiasa menghormati, menghargai perbedaan yang ada pada warga sekolah dengan latar belakang nilai agama, suku, ras, bahasa, etnis dan golongan yang ada di sekolah, baik terhadap peserta didik, guru, karyawan, staf kependidikan maupun komite sekolah dan semua komponen yang berkepentingan dengan sekolah.

Berdasarkan hasil observasi dan wawancara dengan salah satu guru MIS Jamaluddin melalui wawancara pada hari kamis 10 juni 2021 yang menyatakan bahwa: "Pada intinya peran saya sebagai guru dalam implementasi nilai pendidikan multikultural di sekolah yaitu: dengan kegiatan intrakurikuler. Dalam kegiatan intra misalnya saya selalu memberikan pemahaman kepada peserta didik pentingnya menjaga keberagaman dan saya lakukan itu melalui penguatan materi keberagaman di kelas, pada diskusi siswa saya tetap utamakan komunikasi 2 arah yang humanis seperti layaknya seorang seorang anak dan orang tuanya. Selanjutnya peran yang saya lakukan adalah sebagai fasilitator yang berusaha memahami keunikan tiap individu di kelas (W.G.10.06.2021). Guru memperhatikan anak secara personal dan menjalin hubungan yang humanis bukan otoriter. Melalui komunikasi 2 arah, terjalin relasi seperti layaknya teman. Guru selalu mengutamakan komunikasi, diskusi dan kesepakatan kepada anakanak. Komunikasi dan kesepakatan dilakukan kepada semua anak termasuk anak berkebutuhan khusus. Melalui diskusi, perbedaan diolah menjadi hal yang wajar. Setiap diskusi menghasilkan kesepakatan bersama. Melalui kesepakatan bersama guru menerapkan nilainilai universal kemanusiaan Kemudian, peran guru dalam menerapkan pendidikan multikultural di kelas yaitu guru berperan sebagai fasilitator, guru berperan memahami keunikan individu dan guru berperan membangun hubungan yang humanis kepada setiap anak, orangtua dan masyarakat. Peran tersebut, sejalan dengan konsep pendidikan multikultural yang dibangun oleh MIS Jamaluddin: Menerapkan keadilan sosial melalui memberi kesempatan setiap anak untuk mengalami proses belajar. Anak berkebutuhan khusus juga memiliki kesempatan belajar di MIS Jamaluddin. Menerapkan kemanusiaan melalui memberikan ruang kepercayaan 
kepada anak, dialog, kesepakatan dan tidak menjauhkan anak dari lingkungannya.

\subsubsection{Pentingnya Pendidikan}

Multikultural bagi Peserta Didik

Penanaman nilai-nilai melalui sistem pendidikan saat ini telah mengalami penurunan, di samping materi tentang budi pekerti yang berorientasi pada unsur homogenisasi tidak menghasilkan sebagaimana yang diharapkan. Untuk itu, peran pendidikan multikutural perlu diterapkan melalui pendidikan dasar sampai pendidikan tinggi, karena melalui penerapan pendidikan multikultural dapat membantu siswa mengerti, menerima, dan menghargai orang dari suku, budaya dan nilai yang berbeda (Praptini, 2017).

Puspita (2018) menyatakan pendidikan multikultural adalah pendidikan yang berlandaskan pada asas dan prinsip konsep multikulturalisme yakni konsep keberagaman yang mengakui,menerima dan menegaskan perbedaan dan persamaan manusia yang dikaitkan dengan gender, ras, dan kelas, agama berdasarkan nilai dan paham demokratis yang membangun pluralisme budaya dalam usaha memerangi prasangka dan diskriminasi.

Adapun pentingnya pendidikan multikultural bagi peserta didik yaitu sebagai sarana alternatif pemecahan konflik, peserta didik diharapkan tidak meninggalkan akar budayanya, dan pendidikan multikultural sangat relevan digunakan untuk demokrasi yang ada seperti sekarang ini. Berdasarkan penjelasan tersebut di atas bahwa memang penting pendidikan multikultural dilakasanakan disekolah dasar agar peserta didik dapat memahami tentang keberagaman dan cara menghargai sebagai wujud nyata mencintai bangsa Indonesia yang majemuk ini. Selain dari pada itu para peserta didik sejak dini memahami perbedaan-perbedaan keragaman itu sebagai karunia Tuhan Yang Maha Esa yang patut di syukuri sehingga dalam implementasi nilai multikulturalisme dalam kehidupan sehari-hari dapat diinternalisasi dengan baik oleh peserta didik sekolah dasar baik di sekolah, keluarga, dan masyarakat. Seperti yang dijelasakan dalam tujuan pendidikan multikultural dalam UU Sisdiknas ialah: menambahkan sikap simpati, respek, apresiasi dan empati terhadap penganut agama dan kultur yang berbeda.Tujuan utama dari pendidikan multikultural adalah untuk menanamkan sikap simpatik, respek, apresiasi, dan empati terhadap penganut agama dan budaya yang berbeda.

Gorski dalam Budianta, (2003:13) pendidikan multikultural bertujuan untuk memfasilitasi pengalaman belajar yang memungkinkan peserta didik mencapai potensi maksimal sebagai pelajar dan sebagai pribadi yang aktif dan memiliki kepekaan sosial tinggi di tingkat lokal, nasional dan 
global serta mewujudkan sebuah bangsa yang kuat, maju, adil, makmur dan sejahtera tanpa perbedaan etnik, ras, agama dan budaya. Dengan semangat membangun kekuatan diseluruh sektor sehingga tercapai kemakmuran bersama, memiliki harga diri yang tinggi dan dihargai bangsa lain.

\section{Kesimpulan}

Berdasarkan hasil penelitian ini dapat disimpulkan bahwa implementasi nilainilai pendidikan multikultural dalam kehidupan di MIS JAMALUDDIN. Dilaksanakan secara terpadu melalui kegiatan intrakurikuler. Kegiatan yang sangat beragam, disesuaikan dengan minat dan bakat peserta didik. Hal itu dilakukan agar peserta didik dapat mempraktikan secara langsung sesuai dengan dunia nyata. Kegiatan intrakurikuler disekolah dapat dilakukan dengan penguatan materi tentang keberagaman yaitu tentang beragam suku, budaya, agama dan adat istiadat. Dalam proses implementasi pendidikan multukultural tersebut juga tidak terlepas dari peran penting dari kepala sekolah, guru.

Oleh karena itu peran penting pendidikan multikultural dilakasanakan disekolah dasar agar peserta didik dapat memahami tentang keberagaman dan cara menghargai keberagaman tersebut sebagai wujud nyata mencintai bangsa Indonesia yang majemuk ini. Selain dari pada itu para peserta didik sejak dini diajarkan memahami perbedaanperbedaan keragaman itu sebagai karunia Tuhan Yang Maha Esa yang patut di syukuri sehingga dalam implementasi nilai multikulturalisme dalam kehidupan sehari-hari dapat diinternalisasi dengan baik oleh peserta didik sekolah dasar baik di sekolah, keluarga, dan masyarakat.

\section{DAFTAR PUSTAKA}

Anggito, A., \& Setiawan, J. (2018). Metodologi penelitian kualitatif. Sukabumi: CV Jejak (Jejak Publisher).

Baldah, Wardatul. Sumarna, Cecep dan Yuniarto, Bambang. 2016. Pengaruh Penanaman Nilai-nilai multikultural Terhadap Pembentukan Sikap Pluralis Siswa di MTS Negeri Babakan Ciwaringin Kabupaten Cirebon. Jurnal Edueksotis, 1 (1).

Budianta, M. (2003). "Multikulturalisme dan pendidikan multikultural: Sebuah Gambaran Umum". Tsaqafah Vol 1, No. 2 P: 8-16

Dike, Daniel. (2017). Pendidikan Multikultural Sekolah Dasar di Wilayah 3T. Jurnal DIDIKA: Wahana Ilmiah Pendidikan Dasar Vol 1, No. 2: 12-22.

Desmita. 2016. Pikologi Perkembangan Peerta Didik. Bandung: Remaja Rosda Karya.

Hanum, Farida dan Rahmadonna, Sisca. 2010. Implementasi Model Pembelajaran Multikultural SD di DIY. Jurnal Penelitian Ilmu Pendidikan, 3 (1): 89- 102.

Lincoln, P. Z. 2011. Educational Equality or Educational Equity. NUCB Journal of Economics And Information Science, 60 (1).

Milles, \& Huberman. (2013). Qualitative Data Analysis: A Methods Sourcebook. Los Angeles: SAGE Publications.

Moleong, L. (2017). Metodologi Penelitian Kualitatif. Bandung: PT Remaja Rosdakarya. Dipetik September 27, 2020. 
Najmina, Nana. 2018. Pendidikan Multikultural dalam Membentuk Karakter Bangsa Indonesia. Jurnal Pendidikan Ilmu-Ilmu Sosial 10 (1): 52-56.

Praptini (2017). "Peranan Pendidikan Multikultural Dalam Menanamkan Pendidikan Nilai Untuk Membentuk Masyarakat Yang Menghargai Budaya Bangsa" Jurnal Unimed.

Sarona Gaharu (2014). "Peran Guru Dalam Menerapkan Pendidikan Multikultural (Studi Di SD Sanggar Anak Alam Bantul)". Skripsi S1 Sosiologi Universitas Gadjah Mada.

Sudrajat. 2014. Pendidikan Multikultural Untuk Meningkatkan Kualitas Pembelajaran IPS di SD. JIPSINDO, 1 (1): 1-19.

Sugiyono. (2018). Metode Penelitian : Kuantitatif, Kualitatif, dan R\&D. Bandung: Alfabeta.

Undang-undang Republik Indonesia Nomor 20 Tahun 2003 tentang Sistem Pendidikan Nasional.

Wahyudin, Apri dan Elhefni. (2017). Strategi Pengembangan Pendidikan Multikultural di Indonesia. Jurnal Elementary, 3.

Yenny Puspita (2018), "Pentingnya Pendidikan Multikultural" Prosiding Seminar Nasional 21 Universitas Pgri Palembang 05 Mei 2018 Isbn 978602-52451-0-7

Zamroni. (2011). Pendidikan Demokrasi pada Masyarakat Multikultural. Yogyakarta: Surya Sarana Grafika.

Zubaidi. (2004). “Telaah Konsep Multikulturalisme dan Implementasinya dalam Dunia Pendidikan". Hermina Vol.3 no.1.p.77 